International Review of Social History 43 (1998), pp. III-I35

(C) 1998 Internationaal Instituut voor Sociale Geschiedenis

\title{
Octave Mirbeau and the Changing Nature of Right-Wing Political Culture: France, I870-I9I4
}

\author{
SHARIF GEMIE*
}

Summary: Octave Mirbeau was a committed supporter of right-wing politics in the I870s, and a committed opponent of the right wing during the Dreyfus Affair. This paper examines the reasons for his political change of heart, and discusses his changing analyses of right-wing political culture. Mirbeau's ideas are compared with those of some of his contemporaries, such as Blum, Peguy and Sorel.

Right-wing political culture changed dramatically during the first four decades of the Third Republic. As Robert Anderson noted some twenty years ago, in the I870s the French right was represented in parliament by oldfashioned and public spirited country gentlemen; by 19I4, France had an extreme nationalist movement, anti-parliamentary and anti-Semitic, whose ideas and tactics anticipated fascism. ${ }^{I}$ The polarization of two rights suggested in this passage is too simple, but there can be no doubt that something significant did change within French right-wing politics in the late nineteenth century. The nature of these changes has been the subject of a protracted historiograpical debate, often linked to the issue of France's relationship to European fascist movements. Some historians - such as René Rémond - have argued that while a number of new right-wing movements did develop in France during the late nineteenth and early twentieth century, none of these truly resembled fascism. Others - such as Zeev Sternhell - have argued that, on the contrary, there was a full prefiguration of fascism in France, even prior to 1914. ${ }^{2}$ In this paper I wish to provide a commentary on these debates through a study of the writings of a single observer: Octave Mirbeau (1848-1917). ${ }^{3}$

\footnotetext{
* The author would like to thank Patricia Clark, Ruth Kinna and Pierre Michel for their useful comments on earlier drafts of this paper.

I. R.D. Anderson, France, I870-19I4: Politics and Society (London, 1977), p. Ioo.

2. Key works by the two authors are René Rémond, La Droite en France (2nd ed., Paris, 1963), and Zeev Sternhell, La droite révolutionnaire, I885-I9I4 (Paris, 1978). For a useful commentary on this debate, see Brian Jenkins, "Debates and Controversies; Robert Soucy and 'the Second Wave' of French Fascism”, Modern and Contemporary France, 4, 2 (1996), pp. 193-205.

3. Biographical introductions to Mirbeau can be found in: Reg Carr, Anarchism in France: The Case of Octave Mirbeau (Manchester, 1977); and Isabelle Genest, "Octave Mirbeau: The Ravachol of Literature? The Case of an Anarchist Intellectual, I884 to I898", Modern and Contemporary
} 
The differentiation between an "old" and "new" right is clearly too simple. Instead, perhaps it would be more useful to think in the following terms. There was a "primary" form of right-wing political culture, drawn directly from the informal, gentlemanly forms of sociability among the landed elite in the late eighteenth and early nineteenth century, and intellectually oriented around an "instinctive", often unsophisticated faith in the "natural" right of the King and aristocracy to rule, perhaps with the qualification that their hegemony should be expressed through a loose representative structure. Such ideas were rendered in a more polished form by writers such as Bonald, Maistre, Lamennais and - in a more self-critical form - by Chateaubriand. ${ }^{4}$ A number of other models of right-wing political culture developed during the nineteenth century. The Orleanists suggested a more rational, more politicized approach to the tradition of the French Revolution, and tried to negotiate a compromise between the monarchist and republican traditions. However, as a political force, Orleanism was never able to create a popular following.

Right-wing activists looking for popular support usually had two strategies available to them. ${ }^{5}$ The first to be developed was that of "popular monarchy", whereby monarchists would argue that a paternalistic and powerful king was better able to look after the welfare of the French people than a republic. Such ideas, on occasion, acquired some real popular resonance in areas such as Brittany and the Midi. The second strategy was one which was developed during Mirbeau's lifetime: this was a "national" strategy, whereby the concept of the nation replaced that of the king as the centre of right-wing political culture.

\section{MIRBEA U}

Why Mirbeau? Many readers will know Mirbeau as the author of the Journal d'une femme de chambre, which was later used as the basis for a film script by Luis Bunuel. Others may know of his misunderstood novel Le Jardin des supplices, a "succès du scandale"; of his interventions in the Dreyfus Affair; or of his innovative art criticism which publicized the work of the Impressionists to a wide public. Yet none of these facets of Mirbeau's work justify our concentration on his writing.

Instead, one must look to the widening range of "Mirbeau studies" in order to understand how his works can usefully contribute to our under-

France, 46 (1991), pp. 17-28. For a fuller analysis, see Pierre Michel and Jean-François Nivet, Octave Mirbeau: l'imprecateur au coeur fidèle (Paris, 1990). Mirbeau's politics are discussed in my "Mirbeau and Anarchism", Anarchist Studies, 2, I (1994), pp. 3-24.

4. See Rémond, La Droite en France. For a thoughtful introduction to this strand of thought, see Isaiah Berlin, "The Counter-Enlightenment", in his Against the Current (London, 1979), pp. I-24. 5. For an incisive analysis of these strategies, see Robert Gildea, The Past in French History (New Haven, 1994), pp. 298-340. 
standing of right-wing politics. First, Mirbeau had direct, personal experience of many forms of right-wing culture. In the I870s, he worked in minor positions on a succession of right-wing papers such as the Bonapartist $L^{\prime} O r$ dre and the Legitimist Le Gaulois. In the mid-I88os he had a political change of heart, and began to contribute first to Republican papers and then to the anarchist press. It was as a result of this second political commitment that he grew involved in the Dreyfus Affair, where he was thrown into direct opposition to the second form of right-wing politics identified by Anderson. Our first response to the question "why Mirbeau?" is to cite him as an expert witness on right-wing political cultures, someone who had seen right-wing movements both from inside and from outside.

Our second response lies in Mirbeau's status as journalist. Probably when most readers see the two words "anarchist" and "journalist" linked, the immediate image that will spring to mind will be that of a set of marginalized, under-financed, poorly-printed journals, running on goodwill and enthusiasm, wracked by arcane debates on obscure points of political doctrine, and engaged in a permanent struggle to meet the next deadline. This was emphatically not the form of journalism which Mirbeau undertook: he wrote for the mainstream, left-of-centre press, contributing articles, stories and reviews to papers such as the innovative, mass circulation Journal, to the Dreyfusard Aurore, to Brunetière's increasingly conservative Revue des Deux Mondes, as well as to Emile Pouget's syndicalist Père Peinard and Grave's La Révolte. ${ }^{6}$

His journalistic writings were often highly influential. For example, with reference to his commentaries on the art world, a contemporary observer claimed - possibly with some exaggeration - that Mirbeau had "the power to make the fortune of a poor beginner from one day to another". 7 Moreover, Mirbeau assisted in the modernization of art journalism, adopting styles and rhetorical techniques which allowed art criticism to retain a prominent place in the new mass circulation press of the $1890{ }^{8}{ }^{8}$ Mirbeau was a successful and influential journalist in a period when journalism was central to the process of opinion formation: for this reason alone, his writings are well worth investigating in order to understand contemporary

6. On Mirbeau's contribution to the anarchist press, see René Bianco, "Octave Mirbeau et la presse anarchiste", in P. Michel and G. Cesbron, Octave Mirbeau, Actes du colloque international d'Angers du I9 au 22 septembre I99I (Angers, 1992), pp. 53-62.

7. Cited in John Milner, The Studios of Paris: The Capital of Art in the Late Nineteenth Century (New Haven, 1988), p. 64. On Mirbeau's art criticism see Samuel Lair, "L'impressionnisme et ses apôtres: Zola et Mirbeau, divergence des approches critiques", Cahiers Octave Mirbeau (hereafter COM), I (1994), pp. 47-56; Christian Limousin, "Mirbeau critique de l'art: de 'l'âge de l'huile diluvienne' au règne de l'artiste de génie”, COM, I (1994), pp. II-4I.

8. See Martha Ward, "From Art Criticism to Art News: Journalistic Reviewing in Late-Nineteenth Century Paris', in M. Orwicz (ed.), Art Criticism and Its Institutions in Nineteenth-Century France (Manchester, 1994), pp. I62-I8I, esp. I67-I68. 
reactions to the changing nature of right-wing politics. ${ }^{9}$ Such a focus reflects recent developments with historiography, moving away from an assumption of the centrality of the articulate, precise words of political philosophers, to study points of mediation, where political cultures are constructed, through institutions such as folklore, ritual, demonstrations and, by the late nineteenth century, journalism.

However, Mirbeau was not simply an expert witness, and he was more than "the right man in the right place". For decades after his death he was stigmatized as a mere caricaturist or, worse still, as a pornographer. Since the 1980s, thanks largely to the single-minded efforts of his most recent biographer, Pierre Michel, another aspect of Mirbeau has begun to emerge. Michel writes of "the depth and diversity of [Mirbeau's] works, [which reveal] the fascinating richness of this exceptional man". ${ }^{\text {Io }}$ We can only second these sentiments: Mirbeau had something to say about his society, and his thoughts and passions remain relevant to historians. His images and analyses of right-wing political cultures in late nineteenth- and early twentieth-century France will therefore form the basis of this study.

What we propose to undertake is an analysis of three broad themes which emerge in Mirbeau's work. Our studies will loosely run parallel to the development of his political commitments, but it is not our intention to present a biographical study. Rather, we wish to show why a certain form of the "old" right could still command loyalty in the late nineteenth century, how right-wing cultures were renovated and, finally, how left-wing analyses of the nature of the right changed during this period. As our interests concern Mirbeau's writing and their public status, we will not attempt a psychological analysis of Mirbeau's undoubtedly troubled mind, nor attempt to gauge to what extent any particular work is a true reflection of his "real" feelings, or merely an example of literary hack-work, in which Mirbeau is singing the political tune of his paymaster. We will draw examples and evidence from the wide range of Mirbeau's writing, including political polemics, short stories, full-length novels, essays, a utopian sketch, travel writing, and various forms of artistic and literary criticism. To some extent, this mixture of genres is inevitable: as Michel has noted "for Mirbeau as for Zola, everything was linked; literary, artistic and political battles could not be separated; and all of them were rooted in the same vision". ${ }^{\text {II }}$ Occasionally such forms of historical analysis, which include consideration of fictional sources as

9. On the status of the journalist and writer see Alain Pagès, La bataille littéraire; essai sur la réception du naturalisme à l'époque de "Germinal" (Paris, 1989), pp. 7-13, and my "Authors, Markets and Cultural Politics in the Fin-de-Siècle”, Modern and Contemporary France, 4, I (1996), pp. $4 \mathrm{I}-5 \mathrm{O}$.

Io. Pierre Michel, Les Combats d'Octave Mirbeau (Paris, I995), p. Iо.

II. Ibid., p. II. See also Eléonore Roy-Reverzy, "D'une poétique mirbellienne: Le Jardin des supplices", COM, 3 (1996), pp. 30-45, who writes of Mirbeau's refusal of the distinction between journalism and novels. 
material, can worry some historians - usually those who belong to the "a fact is a fact" school of historiography that was demolished by E.H. Carr some thirty-five years ago. There is clearly not enough space to debate such points within this short article: all that can be said is that if it is legitimate to read More's Utopia as an expression of Renaissance social concerns, to read Nietzsche's Thus Spoke Zarathustra as a critique of nineteenth-century political culture, and to read Orwell's Nineteen Eighty-Four as a warning about the future of socialism, then it is also legitimate for historians to consider the insights offered by the fictional, semi-fictional and quasifictional work of Octave Mirbeau. ${ }^{\text {I2 }}$

\section{CONSERVATIVE HUMANISM}

One can question whether the word "political" is the appropriate term to describe Mirbeau's first commentaries on the last years of the Second Empire and the early years of the Third Republic. Instead, as a teenager and as a young man, he seems to write more as a moralist, expressing deep suspicion of the new Republican political sphere, and siding with the apparently "organic" world of small rural community. Such views can be compared with values upheld by those who applauded the "apolitical" rule of the rural notables. ${ }^{13}$

Mirbeau grew up as a lonely boy in a small town in Normandy during the Second Empire (1852-1870). He was sent to a prestigious Catholic secondary school in Vannes, through which he acquired a deep anti-clericalism and a lasting atheism. However, he was relatively slow to identify with any particular political tradition; an uncertainty no doubt made worse by the restrictions on open political debate enforced by the Second Empire and a Catholic college. His confusion is recorded in his semi-autobiographical novel Sébastien Roch, which describes his life at the college. In one episode the hero is asked by an older boy whether he supported Chambord (the Legitimist pretender) or the "Usurper" (Napoleon III): he does not know how to reply. ${ }^{\text {I4 }}$

Some indications of the young Mirbeau's politics do emerge from the letters he wrote to a friend between 1862 and 1874 . On the one hand, he boldly describes himself as a "son of the Revolution", and writes insulting comments about the reactionary Catholic populist Louis Veuillot. ${ }^{15}$ On the

I2. In undertaking this form of study I am loosely drawing inspiration from Clifford Geertz's essay "Ideology as a Cultural System", contained in his The Interpretation of Cultures (London, I993), pp. 193-232.

13. On this point see Rémond, La Droite en France, pp. 96-98.

I4. Sébastien Roch, in Les romans autobiographiques, ed. R. and P. Wald Lasowski (Paris, I99I) (hereafter RA), pp. 675-1079, esp. 766.

I5. Octave Mirbeau, Lettres à Alfred Besnard des Bois, ed. P. Michel (Montpellier, 1989), pp. I04 and 60. 
other hand, contrasting themes are also present. Surprisingly, considering his later misogyny, there are many eloquent, sentimental expressions of a deep homesickness. "College! How bitter is that word! To leave a mother's arms to return to the rigorous surveillance enforced by these strict masters!" ${ }^{16}$ Such passages are politically ambiguous. Taking them at face value, one could say that their hostility to the Catholic college suggests anti-clericalism, even Republicanism. Yet there also seems to be another aspect to them, a stance which sets the closed, intimate world of the family against the public, organized world of the college. The political potential of such expressions becomes more obvious when he turns to discuss conscription. Understandably, the young Mirbeau was against universal conscription, which in these early letters he associates with "ferocious republican virtues". ${ }^{17}$

The point here is that there is nothing inevitably left-wing about Mirbeau's politics. His first political steps are to defend the small, closed world of home, family and friends against the big public world of church, school and army. Many right-wing activists of the late nineteenth century shared these emotions: one could cite, for example, "Gyp" whose experiences in a Jesuit secondary school also left her with a lasting anti-clericalism, but which never led her to take left-wing views. ${ }^{18}$

Given these assertions of small-town humanism, it seems paradoxical that Mirbeau is then recruited to work on a Bonapartist paper (in I872). Surely Bonapartism was the most militaristic, the most centralizing of all the French political traditions of the I87os? There are a number of responses to this point. One is to argue that Mirbeau was acting opportunistically, that he was willing to do anything to escape the legal career to which his family was directing him. Moreover, to a young man who grew up in the I86os, Bonapartists might still appear as privileged representatives of nineteenthcentury political culture, and as people with real access to power.

A second, more subtle, response would be to point to Mirbeau's reading of Bonapartism. His political choice resembled that taken by Albert Richard, who in the late I860s was a representative of the Bakuninist wing of the First International in Lyon, but who, in 1872 , also came to voice sympathy for the Bonapartist cause. ${ }^{19}$ The ideology that attracted young men such as Mirbeau was not a militaristic creed, but a voice of moderation and reconciliation, which refused both the divine right of kings and the

16. Ibid., p. 38.

17. Ibid., p. 62. His comments can be compared with peasant resentment of the army: see Eugen Weber, Peasants into Frenchmen (London, 1979), pp. 292-302.

I8. See Willa Z. Silverman, The Notorious Life of Gyp: Right-Wing Anarchist in Fin-de-Siècle France (Oxford, 1995), p. 28.

19. On Richard and Bonapartism in the early I870s, see Bernard Ménager, Les Napoléon du Peuple

(Paris, 1988), pp. 26I-310. 
revolutionary rights of barricades, ${ }^{20}$ a movement which sought to conserve the legacy of the French Revolution, and to unite classes in social harmony. After all, it was not the Second Empire which had crushed the revolt of the Paris Commune (I87I), but the Third Republic. As Michel points out, the Bonapartism of the early Third Republic resembled more a proto-Gaullism than a proto-fascism. ${ }^{2 \mathrm{I}}$ Perhaps, lastly, we should note the existence of a quasi-socialist wing within this new Bonapartism, led by Jules Amigues, which was making a spirited effort to recruit working-class activists, and whose imaginative polemical writing may have attracted the young Mirbeau's attention.

Many elements within Mirbeau's early Bonapartist writing reflect his small-town conservative origins. This can be seen particularly clearly in his early art criticism, which was the form of writing which allowed him the greatest freedom to express his opinions. ${ }^{22}$

When reviewing the prestigious annual exhibition of the Salon, Mirbeau is happiest when he is able to satisfy his "deeply rural tastes" ${ }^{\text {"23 }}$ by reviewing landscapes.

Anyone who has not lived all their life in the smoke of Paris will recognize it, and anyone who isn't exhausted, or atrophied to the point that they have lost the healthy passion for rural life, must feel, as they stand in front of this painting, wonderful memories and the desire for the fields.. This is the country, the true and good countryside. What a rustic smell! What robust poetry! ${ }^{24}$

Of course, such admiration for rural landscapes contradicted the received wisdom of the Salon jury, which valued classical, historical paintings most. ${ }^{25}$ Did Mirbeau intend to present a challenge? Perhaps. He certainly rehearsed the argument that he would deliberately ignore established classifications and genres, and that he would only use "simple, ordinary" words to describe painting. ${ }^{26}$ Yet in other passages, one can sometimes hear another theme. For instance, consider the following introductory passage to his 1875 Salon review.

At the end of the day, what is an exposition by the Ecole des Beaux Arts? An Academy? An Assembly? Is it somewhere to visit if you want a sleepy atmosphere,

\footnotetext{
20. "Le Salon", in Octave Mirbeau, Premières Chroniques Esthétiques, ed. P. Michel (Angers, 1996) (hereafter PCE), pp. I65-I68, esp. I67, 3 May I876.

2I. On this point, see Pierre Michel, “Octave Mirbeau et l'Empire", Littérature et Nation, I3 (1994), pp. I9-42.

22. See the useful description of Mirbeau's early aesthetic writings given by Christian Limousin, "Octave Mirbeau, critique d'art 'nègre", COM, 3 (I996), pp. 95-IIO.

23. "Le Salon", PCE, pp. III-II4, esp. III, 5 May I875.

24. Ibid., pp. 199-204, esp. 199-200, 24 May 1876.

25. On the jury's aesthetics see Harrison C. and Cynthia A. White, Canvasses and Careers: Institutional Change in the French Painting World (New York, 1965), pp. 91-92; and T.J. Clark, The Painting of Modern Life: Paris in the Art of Manet and his Followers (London, 1990), pp. 89-99. 26. "Le Salon", PCE, pp. 28-3I, esp. 30, 3 May I874; ibid., pp. 94 and 98, 5 May I875.
} 
heavy with academic nightmares? No! Let's speak frankly: a Salon is quite simply a place where you breathe in a lot of dust while looking at a lot of pictures on the first floor and a lot of statues on the ground floor. ${ }^{27}$

This sort of crude anti-intellectualism suggests that Mirbeau's refusal to accept complex systems of artistic classification may result as much from his genuine confusion about them, from his sense of intimidation before four thousand paintings, ${ }^{28}$ rather than from any proto-anarchist rebellion. In his Bonapartist politics and in his Salon criticism, we can see similar impulses at work: a refusal to accept divisions, subtleties, intricacies, or nuances, and an assertion of a cultural and social simplicity which takes provincial, rural France as its ideal reference point.

Other forms of writing show a more aggressive side of Mirbeau's early thought. An article by him which attracted widespread public attention was published by the right-wing Le Figaro in October 1882. He was disgusted by the rise of a new class of public celebrities: not the poor artists and writers who often had to work for twenty years before their work gained any sort of recognition, but the rich actors who played to crowded rooms in theatres and cafe-concerts. ${ }^{29}$ Past societies had treated actors as pariahs; in the I870s and I880s they were still banned from burials in consecrated ground. Their rise to prominence in the 1870 s was proof of the nation's decadence; the actor's status epitomized the transitory, formless nature of Republican France. By portraying a series of different conditions and characters, actors had forfeited their own identity. They had no personality, no face, and no individual creativity, for their role was essentially a passive one: that of representing someone else's lines. Rather than rising above the mob, actors instead represented a type of concentration of the mob's feelings and values. As such, for Mirbeau, they were the perfect representation of the Republicans' reign, whose cultural policies seemed equivalent to the debasement of the French population. ${ }^{30}$

More worrying than these illegitimate leaders were those who followed them. Mirbeau scorned the urban, umbrella-carrying masses who crowded out the Salon's dusty galleries. They had no sense of independence: it was they who fell for the self-serving advice of the Salon jury in the same way

27. PCE, p. 94, 3 May I875.

28. "Le Salon", PCE, pp. 219-222, esp. 219, 2I June 1876.

29. Mirbeau, "Le Comédien", in Octave Mirbeau, Combats Politiques, ed. Pierre Michel and Jean-François Nivet (Paris, I990) (hereafter CP), pp. 43-50, 26 October 1882. On the rise of the café-concert and theatre, see Robert J. Herbert, Impressionism: Art, Leisure and Parisian Society (New Haven, 1988), pp. 59-I40. Mirbeau's writing on acting can be compared with Tolstoy's polemic against the theatre, in his "What is Art?", contained in What is Art? and Essays on Art, trans. A. Maude (Oxford, I975).

30. See "Ode au choléra", CP, pp. 57-64, esp. 60, 2I July I883. 
that they fell victim to the fashionable disease of anaemia. ${ }^{3 \mathrm{I}}$ It was they who cheered the actors in the café-concerts and theatres, and who supplied the electoral base for the Republic's destructive rule. "What the Germans couldn't do, the French have done: what the enemy left standing, the republicans have toppled. They attack men, beliefs, and the country's secular traditions." ${ }^{32}$ The Republic brought "little oligarchical groups"33 to power; its rule allowed the art world to be dominated by an art bourgeoisie. ${ }^{34}$ These men presided over the decline of French art, for the Republic "does not inspire". 35 The decline of quality of works exhibited in the Salon, and the blind acceptance of this decline by "the crowd", demonstrated the fate of the whole of France.

Mirbeau hated all these forces which seemed to threaten or disturb the small, fixed world of home, family and friends. However, his emotions did not lead to clear political commitments. They could imply an element of elitist anti-bourgeois feeling, but this did not necessarily prefigure any form of left-wing politics: as Paul Lidsky has demonstrated, vague, shallow, antibourgeois sentiments were almost obligatory among artistic and cultural circles. ${ }^{36}$ An example of the young Mirbeau's non-political use of the term "bourgeois" can be found in his Salon writing of I874. He noted that a painting by Marcellin Desboutin would not please the bourgeoisie and then distinguished between those who, like Desboutin, painted for the elite, and those who painted for "la foule" (the mob or the crowd). ${ }^{37}$ Here, it is clear that Mirbeau, like Balzac, uses the term as an apolitical insult, equating "the bourgeoisie" with "la foule". ${ }^{38}$

For Mirbeau, these changes created by the Republicans' rise were not simply political processes; they were the victory of one type of psychology over another. "Today, in our cramped, sickly democracy, nervousness is the symbol of power: not the calm, full, impassive power of the male, but a worried, troubled force, a slave to its passions, like that of women." ${ }^{39}$ This process was at its most concentrated in the capital. In Mirbeau's first fulllength novel, Le Calvaire (I886), Paris and the provincial society are compared.

31. "Tous anemiques", in Octave Mirbeau, Paris Déshabillé, ed. Jean-François Nivet and Pierre Michel (Caen, 1991) (hereafter PD), pp. I5-20, I2 June I880.

32. "Ode au choléra", p. 59.

33. "L’Art dans la rue", PCE, pp. 230-233, 27 August I876.

34. "Le règlement du Salon sous l'Empire et sous la République", PCE, pp. 245-247, 24 November I876.

35. "L’Art sous la République", PCE, pp. 237-240, 9 September 1876.

36. Paul Lidsky, Les écrivains contre la Commune (Paris, 1982), pp. 19-27.

37. "Le Salon", pp. 64-68, esp. 66-67, 28 May 1874.

38. On Balzac's concept of class, see S. Gemie, "Balzac and the Moral Crisis of the July Monarchy", European History Quarterly, 19, 4 (1989), pp. 469-494.

39. "Les nerveux", p. 24. 
[In my village] I had reference points to guide me: a peasant's back as he bent over the soil, an old cottage at the bend in the road, a fold in the land, a dog, a marlpit, a charming face: everything was familiar to me, as if it was precious. In Paris, everything was unknown and frightening. The tremendous speed with which they acted, their deep selfishness, the way they forgot each other [...] how could you catch these people's attention for a moment? I am not talking about attracting their sympathy or care, but just a look! ${ }^{40}$

Paris was the arena "where victory goes to the strong, the ambitious and the nervous" ${ }^{4 \mathrm{I}}$ This sense of dispossession, of the replacement of a legitimate ruling class by an illegitimate facsimile, which these passages express is clearly compatible with xenophobic and anti-Semitic politics. These themes became clearer in some of Mirbeau's writings in the early I88os.

Paris, town of the distant masses, prostitute-city who gives herself to whoever pays, is no longer the capital of France. It is the anonymous capital of all men who have no nation and no name [...] [it is invaded by] foreign commerce, [from] the dusty bazaars of the Orient, the despised ghettos of Germany.

At their head was the Jewish Baron Rothschild, who represented "the base instincts, the greedy instincts, the corruption" of "the people". ${ }^{2}$ Such ugly ideas are clearly typical of late nineteenth-century anti-Semitism, within which Jews are stigmatized as both the symbol and the cause of all the resented aspects of cultural and social modernity. ${ }^{43}$ To anti-Semitic critics of the I880s and I89os, the apparent rise of the Jews epitomized the formless, fragmentary moral chaos introduced into France by Republican rule, for Jews were seen as a rootless, drifting people. In Mirbeau's writing, bankers and actors, Republicans and Jews were all seen as working in common for the decay and degeneration of an older, provincial, honourable France. While these groups may have reached positions of power, they did not, in the true sense of the word, "lead", for this would imply raising the culture and morality of the masses. Instead, they followed corruption downwards.

Within these images, a consistent set of concepts can be identified: the foolish, short-sighted, "bourgeois" masses of Paris are linked to their manipulative, crafty leaders who, whether actors or bankers, Jews or Republicans, do no more than represent the masses' worse instincts to themselves. Mirbeau, at this stage in his writing, is not making use of the vocabulary of class, nor that of politics, but instead his thinking is based on a simple, moralistic polarization of the healthy life of the provinces and the sick degeneracy of Republican Paris.

As Mirbeau surveys the condition of France, few people attract his praise.

40. Octave Mirbeau, Le Calvaire, in RA, pp. 7-336, esp. 49.

4I. "Les nerveux", pp. 2I-27, esp. 23, 22 June I880.

42. "L'invasion", CP, pp. 65-71, esp. 65, I5 September 1883.

43. See the exhaustive analysis of anti-Semitism in Steven Wilson, Ideology and Experience; Antisemitism in France at the Time of the Dreyfus Affair (London, 1982). 
Despite his later admiration for the Impressionists, in the I870s he was suspicious about them, tending to see them as deliberately courting trouble. ${ }^{44}$ While admiring Manet, he felt less admiration for the "bunch of ignorant youths who are so proud of their ignorance" whom Manet had inspired. ${ }^{45} \mathrm{He}$ finds only a couple of examples of groups who seem capable of resisting the rising tide of Republican corruption. Curiously enough, these both concern women.

In I880 Mirbeau considered the Republicans' rise. In an essay entitled "Maison neuve", he noted that while "they have done a lot, spoken a lot, smiled a lot", they still failed to attract the support of women. He provided the following explanation for this failure.

Woman is a lot more difficult to conquer than brainless magistrates or cracked old generals. She has an invincible sense of disgust, a stubborn sense of resistance and, above all, a fine sense of smell which can detect, beneath the perfumes which these [republican] gentlemen spray on themselves, the acrid stench of old filth. ${ }^{46}$

Of course, this praise for women's ability to spot dirt does not constitute any form of "feminist" sympathy. Mirbeau is citing "woman" as an instinctive creature, an unthinking representative of the closed, fixed provincial societies which attracted his sympathy.

Our second example follows a similar line of reasoning. Mirbeau wrote an article applauding the works produced by female artists, and asserting their right to paint and to exhibit works. These "femmes du monde" (fashionable women) brought unique qualities to the art world.

They will teach [...] the laws of true and aristocratic delicacy. They will give the craft a soul, and pull out of matter a new sensation. Nobody could deny the tact, the strength, the creativity and the ingeniousness with which these ladies design their homes. These queens of beauty and elegance, whose clothes [...] are, in themselves, master-pieces, produce miracles in design. ${ }^{47}$

While it is unusual to find an article by Mirbeau which praises female creativity, one can still note the consistency of the political currents within his writing. He is applauding the new cult of domesticity: it is woman as housewife whom he proclaims as the saviour of the art world, not woman emancipated from the charges of domesticity. Aside from glimpses such as these, Mirbeau's political and social vision is pessimistic. Rothschild and the actor ruled. No king, no warrior, no riot seemed to oppose the reign of the Jews. ${ }^{48}$ The purity of provincial France was a passive quality: its youth

44. See Limousin, "Octave Mirbeau, critique d'art 'nègre'”.

45. "Deux Expositions", PCE, pp. 269-272, 9 April I880.

46. "Maison Neuve", PD, pp. 35-44, 27 August I88o.

47. "Les femmes artistes", PCE, pp. 26I-264, 3I March I880. For a more serious study of women, domesticity and the art world, see Anne Higonnet, Berthe Morisot's Images of Women (Cambridge, MA, 1992).

48. "Ode au choléra", p. 63. 
was "dead"; they turned to the Stock Exchange for inspiration. ${ }^{49}$ It was in this mood of despair that Mirbeau turned to write his one, brief, utopian sketch.

Perhaps the best term to describe Mirbeau's utopia would be "Tolkienesque", for it seems uncannily similar to the land of the hobbits, "the Shire", celebrating similar qualities of closed, fixed, pre-modern harmony. Mirbeau imagined himself as a paternalistic, benevolent monarch, imitating some features of the "popular monarchy" strategy outlined at the start of this paper..$^{50}$ "My subjects lived in peace, ignorant of everything, but with a clear, calm knowledge of life." ${ }^{\text {"I }}$ Their society is stripped of all the big public institutions which Mirbeau saw as threatening: no ministers, no parliaments, no prefects, no budgets, no schools, no crimes, no papers, no cabarets, no actors, no horse races ... The people of this utopia spend their lives tilling the land, playing boules, singing songs and dancing. In contrast to the passages quoted above, the political principles of this utopia are based on patriarchy taken to its logical extreme, resulting in the abolition of women. This indicates the superficiality of Mirbeau's earlier praise for women's talents: while he might admire their instinctive, unthinking resistance to Republican degeneration, he could not conceive of a female politics as the basis for an honourable polity. His utopian fable ends unhappily.

One day, I got bored and wanted to have a court around me. I had ministers, parlements and law-courts, I made officials, I gave my people women [. . .] A breath of discontent blew across their tranquillity: hatred arose, ferocious, and I was thrown from my throne and chased out my kingdom.

These last phrases reflect developments within Mirbeau's own life. By the early i88os Parisian, right-wing political culture was no longer such a cosy home for our provincial. Patronized, exploited and misdirected by a succession of minor right-wing politicians and editors, Mirbeau was clearly beginning to rethink his political commitments. ${ }^{52}$ Regrettably, even his antiSemitism may have been an expression of his desire to begin a criticism of the received wisdom of the right: it was clearly a deliberate provocation to one of his employers, Arthur Mayer, the Jewish editor of Le Gaulois. ${ }^{53}$ Mir-

49. "L'invasion", p. 70.

50. There is more than a passing resemblance between Mirbeau's utopia and the politics of the Legitimist right: see Steven Kale, "The Monarchy According to the King", French History, 2, 4 (I988), pp. 399-426.

5I. "Royaume à vendre", CP, pp. 5I-56, 29 April I883. Similar images can also be found in a later essay "Paysage Breton", in Octave Mirbeau, Croquis Bretons, ed. Jean-François Nivet (Reze, 1993) (hereafter CB), pp. 63-70, 2I June I887.

52. His semi-autobiographical short story "Un Raté" reveals something of his despair: see Contes Cruels, vol. II, ed. Pierre Michel and Jean-François Nivet (Paris, 1990) (hereafter CCII), pp. 423428, I9 June I882.

53. Mirbeau's own explanation - and apology - for his anti-Semitism can be found in his "Palinodies!", CP, pp. 203-209, is November 1898. For a relevant example of how anti-Semitism could 
beau's idealization of such small, fixed, rural communities was typical of nineteenth-century right-wing political culture. Similar passages could be cited from Léon Daudet's descriptions of Provençal villages, Maurice Barrès' writings about rural Alsace-Lorraine, and Pierre Loti's tales of the French Basques. ${ }^{54}$ Similar images have been found by historians of the French right: by Philip Nord in his research on the politics of Parisian shopkeepers, by Steven Wilson among the anti-Dreyfusards, and by Pascal Ory within the "Greenshirts". ${ }^{55}$ In each case, the admiration for the apparent ethical purity of the small community justified the aggressive, often violent, behaviour which was used to defend it. Perhaps the significant point here is that Mirbeau's evocation of rural life is presented within the context of a utopia. Unlike the other right-wing writers, he was unable to link his ideals to a living example of a provincial community.

In these examples of Mirbeau's early writing, right-wing political culture emerges as primarily negative, conducting a politics of resistance, and endeavouring to save "human" qualities from the rise of republican artificiality. Mirbeau attacks and denounces: he finds few examples of praiseworthy political activity.

However, as the right developed politically during the I880s and I890s, the stress on the purity of the small community ebbed, and the centrality of monarchy was gradually eclipsed. A secular, even Republican, right-wing vocabulary began to emerge.

\section{NEW RIGHT-WING POLITICAL CULTURES AND THE DREYFUS AFFAIR}

The basis for Mirbeau's early conservative humanism was the idea that a gifted, ethical leader could - potentially - energize the moral forces of the small rural communities. While politics could result in aggressive, xenophobic, and even anti-Semitic campaigns, the cultural centre of gravity of such movements lay in the daily culture of the villages and small towns of France, easily distinguishable from the "alien" Republican politics propagated by France's first generation of electorally successful Republican groups. The problem with this conservative approach to politics was that, in practice, it was only capable of resisting the Republicans, not of defeating

function as an auto-critique within the right, see J.-M. Mayeur, "Les congrès nationaux de la democratie chrétienne à Lyon (1896-97-98)", Revue d'histoire moderne et contemporaine, 9 (1962), pp. 17I-206.

54. Léon Daudet, "Souvenirs des Milieux littéraires, politiques, artistiques et médicaux", in Souvenirs et Polémiques, ed. B. Oudin (Paris, 1992), pp. 3-765, esp. 35-55; Maurice Barrès, Colette Baudoche (Paris, 1968); and Pierre Loti, Ramuntcho (Paris, 1964).

55. Philip G. Nord, Paris Shopkeepers and the Politics of Resentment (Princeton, 1986); Wilson, Ideology and Experience; Pascal Ory, "Le Dorgèrisme; institution et discours d' une colère paysanne (1929-39)", Revue d'histoire moderne et contemporaine, 22 (1975), pp. 168-190. 
them. The "natural leaders" of such "organic communities" looked increasingly ridiculous. Visiting a small village in Brittany, Mirbeau could only laugh at his companion, "a poor squire [hobereau] [...] more monarchist than the monarch, more papist than the pope, and one devil of an alcoholic". ${ }^{56}$ Such men proved to be poor leaders in the fight against Republicanism. During the late I870s and I88os, right-wing activists, for the first time, were forced to consider seriously the nature of political, even electoral, organization. Legitimists and Bonapartists both experimented with new forms of administration. ${ }^{57}$ Neither camp managed to square the circle of grafting a new face on to an old political body, and it was in the wake of this failure that the Boulangist crisis gripped Republican France in the late i88os.

The Boulangist movement was a wide-ranging and ultimately contradictory coalition of protest, which managed to include within its ranks nationalists, monarchists, Catholics, radical Republicans and even socialists. Initially, it appeared to many as a new form of left-wing protest against the Republic. ${ }^{58}$ It was in this context that Mirbeau was invited to write a hostile commentary on the movement by a Legitimist paper.

To his credit, Mirbeau quickly understood the dangers presented by this movement. Indeed, this point might well be the key to understanding his political change of heart. He was among the first, from the right or the left, to denounce Boulangism. The manner in which he condemns Boulanger's movement is revealing. He used similar terms to those which he previously used to criticize the reign of the actor and of Rothschild: Boulanger corresponds too easily to mass culture; he is "the General of the Markets".59 Mirbeau understood how Boulangism could serve as an ideology to legitimate the rise of a new ruling class which, while making use of radical slogans, would prove to be harsher and more vindictive than the old conservative hobereaux. Boulangist evocations of France did not signify a new sense of ethical national community, but merely served to mask and defuse the antagonism between powerful and the powerless. ${ }^{60}$ Later nationalist leaders who tried to imitate Boulanger's tactics, such as Déroulède, attracted

56. "Bretonneries", CB, pp. 95-105, esp. 95, 3 November I888.

57. On right-wing attempts to organize politically, see R.R. Locke, French Legitimists and the Politics of Moral Order (Princeton, 1974) and William D. Irvine, The Boulanger Affair Revisited (Oxford, 1989).

58. See Patrick Hutton, "Popular Boulangism and the Advent of Mass Politics in France, I88690", Journal of Contemporary History, II (1976), pp. 85-I06 for an interesting discussion of left-wing tendencies within Boulangism.

59. "Boulanger", CP, pp. 93-IOo, I8 July I886. On Mirbeau's attitudes to Boulangism, see Isabelle Saulquin, "Mirbeau et le boulangisme", COM, 3 (1996), pp. I26-33.

6o. These themes are explored in his short stories "Un mécontent", in Contes Cruels, vol. I (hereafter CCI), pp. 354-360, I7 May I889, and "Monsieur le Recteur", CCII, pp. 236-240, I7 September I889. 
his contempt. ${ }^{61}$ Rather than opposing the corrupting mass culture which Mirbeau saw germinating in the city slums, this newly organized populist right was reinforcing it.

In a sense, Mirbeau was being consistent in his ideas, while - in 1887 , or I888 - the older right-wing groups were changing. ${ }^{62}$ The centre of gravity of right-wing politics seemed to have shifted. The right wing of the I860s and I870s had seemed to be principally a movement of resistance, by which the rise of the Republic might be slowed, if not actually halted. The right which emerged in the I88os seemed to be aiming at a different goal: the active subversion of Republican parliamentary democracy by military forces. In 1867 , the young Mirbeau could associate militarism and conscription with the Republican tradition; by the I890s it was clear that such political themes belonged to the right. ${ }^{63}$ Equally, in the 1870 os he associated demagogy with the Republican left; in the late i88os it seemed the province of the right. The army - or rather a particular interpretation of the role of the army - now seemed at the centre of this "new" right. "It has become the rallying point of all savage hatreds, all barbaric appetites, of all rebellious violence." ${ }^{14}$ The climax of Mirbeau's horror with these themes within rightwing political culture came during the Dreyfus Affair.

This clash did not simply throw two opposing forces against each other: it also clarified the nature of French politics and society. No longer could the cultural milieu of salons and journals appear as an apolitical space. ${ }^{65}$ As Mirbeau noted, "we must bless this Dreyfus Affair for, in a way, having revealed our true nature to ourselves" ${ }^{66}$ The revelation was not a pleasant one: it showed a bloodthirsty, militarist clique which refused to accept any limitation on its power. According to Mirbeau, the Church worked handin-hand with this faction, using papers such as Le Croix to praise their politics and applaud their defiance of constitutional controls. ${ }^{67}$ Reviving an old anti-clerical theme, Mirbeau even argued that the whole Dreyfus Affair was a "Jesuit crime" - although by this phrase Mirbeau did not mean that Dreyfus's arrest had been planned by the Jesuits; rather that their teaching and training set the ethical context within which the anti-Dreyfusard right developed.$^{68}$ In the place of the Tolkienesque utopia of paternalist monarchy which Mirbeau had written in I883, the political culture of the right now

6I. "Vainqueur de son ombre", CP, pp. I97-20I, 24 October I898.

62. See Irvine, The Boulanger Affair Revisited.

63. See, for example, his "Philosophe sans le savoir", CP, pp. I49-I55, Io June I894, which concerns General de Gallifet.

64. "A un prolétaire", in Octave Mirbeau, L'Affaire Dreyfus, ed. Pierre Michel and Jean-François Nivet (Paris, I99I) (hereafter AD), pp. 74-80, esp. 78, 8 August I898. See also the comments of Sternhell, La Droite révolutionnaire, p. 82.

65. On the effects of the Dreyfus Affair on salons, see Silverman, Gyp, pp. IO2-IO6.

66. "Palinodies!", pp. 203-209, esp. 205, I5 November I898.

67. See "En Province", CP, pp. 219-224, esp. 219, 22 July 1899, and "Monsieur le Recteur".

68. “Souvenirs!", AD, pp. 89-93, esp. 93, 22 August I898. 
came to resemble a dystopia: a sinister process of destruction, corruption and murder. It was during this period that he wrote his troubling, impressionistic novel Le Jardin des supplices, which compared the action of government with the functioning of a permanent process of torture. ${ }^{69}$ Such thinking also inspired much of Mirbeau's Dreyfusard journalism: "Having taken from the judges the right to be judges, [the government] will take from men the right to be human. After justice, liberty [will go]; after liberty, life itself." ${ }^{70}$ The Dreyfusards faced a monstrous political growth, which was attempting to subvert all sense of honesty, of ethical legitimacy in public life.

Like Boulangism, this anti-Dreyfusard right made use of nationalism as an ideology. "Their" France was no gentle rural harmony: instead "France, for them, is this paid band of two thousand cut-throat and street-hawkers who terrify the country by their savage screams and death cries. ${ }^{77}$ Even the structures of their propaganda were a form of violence: rather than developing ideas through debate and exchange, anti-Semitic thinkers wove together a web of lies, forgeries and crimes. ${ }^{72}$ In the early i88os, Mirbeau had thought that Jews were agents of cultural decline: by I898 his ideas had changed. By this latter date, he considered the anti-Semites as the stimulators of mob passions, as mere demagogues, as corruptors of French politics. The Jews were simply another victimized group within the general cruelty of the Third Republic.

Significantly, Mirbeau refused to see the Dreyfus Affair as a contest between two political ideologies: instead, like many Dreyfusards, he saw it as an elemental struggle between the forces of falsehood and truth. Like Blum, he must have wondered "how could sincere people be antiDreyfusards?" ${ }^{73}$ But, unlike Blum, Mirbeau noted a different quality in the arguments presented by the two opposing sides. The anti-Dreyfusards were terrified of "enlightening the people", their supporters' speeches were composed of bluster and insult, and they could only win arguments by manipulation, while the Dreyfusard press thrived on "questioning, reading and commentary" ${ }^{74}$ For Mirbeau, the Dreyfusards' campaign seemed, momentarily, like a vast mass experiment in libertarian education: not just teaching "facts", but awakening minds and capacities. While some anarchists felt initially uncertain about the Dreyfusard campaign, Mirbeau had no doubts

69. For a useful study of Le Jardin and its historical context, see Pierre Michel, "Le Jardin des supplices: entre patchwork et soubresauts d'épouvante", COM, 3 (I996), pp. 46-72.

70. "L'iniquité", AD, pp. 229-233, esp. 232, 2 February I899.

7I. "Trop Tard!", CP, pp. I8I-I87, esp. I84, 2 August I898.

72. "Le coup de bistouri", AD, pp. IO6-III, I2 September I898.

73. Léon Blum, Souvenirs sur l'Affaire (Paris, 1981; Ist pub. 1935), p. 56.

74. "Psychologie militaire", AD, pp. 329-334, 6 July I899; "Les voix dans la rue", AD, pp. II9I22, 26 September 1898; "Pour le Roy! II", AD, pp. 318-322, esp. 32I, I5 June I899; see also "La Vérité est morte", COM, I (1994), pp. 213-217, undated (I899-1900?). 
about the urgent need for a movement of solidarity, mobilizing victimized and marginalized groups, that transcended the boundaries of class. ${ }^{75}$

There was a potential contradiction within Mirbeau's analysis of class identity of the anti-Dreyfusards. On the one hand, at times he addressed the anti-Dreyfusard right as if its ideas represented the hegemony of a new ruling class, out to beat the old aristocracy at its own game, and therefore using new ideas and new techniques to enforce its rule. ${ }^{76}$ On the other hand, in the heat of the Affair, he often introduced another theme in his caricatures of the anti-Dreyfusards: they were simply the same stupid, backward-looking aristocracy, merely making use of new forms of propaganda to justify the continuation of their privileged positions within French society. ${ }^{77}$ For example, in a satirical sketch, Mirbeau reports that he has heard a woman cry "Death to the Jews" at her communion, and the priest reply "Long Live the Army!" ${ }^{7}$ This second theme can be seen as a simple continuation of a long tradition of anti-clerical radicalism, rather than a contribution to a distinctive form of socialist radicalism. In Mirbeau's writing the anti-Dreyfusard camp appears as a rallying point of all the forms of right-wing culture, from the "primary" right of the simple monarchists, to the proto-fascism of the nationalist leagues.

The Dreyfus Affair also revealed to Mirbeau the true nature of conservative rural France. In place of the cosy image of village harmony which he assumed rather than described in the I870s, during the I880s Mirbeau had been rethinking the nature of rural society. ${ }^{79}$ His analyses can certainly be faulted for their over-concentration on the villages and peasants of Brittany, studying - for example - a place which he himself described as "one of the most savage corners of Finistère".$^{80}$ However, the image which emerged from this later writing was more challenging and arguably more perceptive than his early texts. Rather than oases of harmony, villages were arenas of tense, inward-looking emotions. "There, isolation, the lack of movement, of words, all work to encourage the growth of sickness. The worst crimes are committed in small towns and in the countryside." ${ }^{" 1}$ Uneducated, fearful, lacking in confidence, such people were unable to confront the rule of the priest and the local notable. It was these people who were most resistant

75. See "A un proletaire". On anarchist attitudes to anti-Semitism and Dreyfus, see Richard D. Sonn, Anarchism and Cultural Politics in Fin-de-Siècle France (Lincoln, NE, 1989), pp. 45-48. 76. See "Un mécontent".

77. See "Pour le Roy!", AD, pp. 312-317, 8 June I899 and "Pour le Roy! II". See also Christian Delporte, "Images d'une guerre franco-française: la caricature au temps de l'Affaire Dreyfus", French Cultural Studies, 6 (1995), pp. 22I-248, who notes the revival of "old anti-clericalism" in the Dreyfusards' propaganda (pp. 243-244).

78. "Pour le Roy!", p. 315.

79. See, for example, his Contes de la chaumière (Amiens, 1987), and the texts contained in CB.

80. "Les eaux muettes", CB, pp. 3I-6I, esp. 3I, I885.

8I. "La Nèvrose au Village", in Octave Mirbeau, Chroniques du Diable, ed. Pierre Michel

(Besançon, 1995) (hereafter CD), pp. IOI-IO7, esp. IO2, 29 March I885. 
to the libertarian message of the Dreyfusards; the Dreyfus Affair "left much of the countryside apparently indifferent" ${ }^{82}$ The rural people were not to blame for their lack of concern with civil liberties and justice. "[The peasant] is to be pitied, for he is a victim, a poor victim of a religious environment. He has been infected with religious poison, up to his neck." ${ }^{83}$

There was another lesson to be learnt from the Dreyfus Affair. Politics was not a simple matter of the imposition of one form of rule: it was a dialectical process which could be transformed by appropriate interventions. Mirbeau argued that the anti-Dreyfusards "only shout because we are silent, they are only strong because of our silence" ${ }^{84}$ Such a situation was not "natural", nor "organic"; it was not the inevitable fate of France to suffer the anti-Dreyfusards' arrogance and menaces. The answer, of course, was to confront their violence.

However, it was not clear where the precise focus of this political struggle was to be situated. Mirbeau, like most of the anarchists of the I89os, had little faith in the effectiveness of parliamentary forms in representing the real political issues of the time..$^{85}$ Initially, the anarchists were sceptical about the idea of working with left-Republicans, liberals and Jewish radicals on issues such as civil rights and legality. ${ }^{86}$ However, for many anarchists, the Dreyfus Affair became a political turning-point. It drew them closer to a defence of the Republic. For some, like the young Leon Blum, this was the moment to shed their youthful anarchist idealism, and to accept the "chivalrous generosity" represented by socialist leaders such as Jaurès. ${ }^{87}$ The SFIO (Section Française de l'Internationale Ouvrière, the French socialist party, created in 1905) seemed to represent a new generation of parliamentary radicalism, qualitatively different from the left-leaning radicals of the nineteenth century. In Blum's words, "we expected to transform [our] coalition into a standing army at the service of Rights and Justice" ${ }^{88}$

While Mirbeau certainly worked with Jaurès and Zola during the Affair, he was less attracted to their parliamentary radicalism. For him, the Dreyfus Affair presented other problems. Twice during the Affair he acknowledged the difficult nature of his own political education: he had been forced to confront his own assumptions, to shed the thinking and motivations which

82. Annie Moulin, Peasantry and Society in France Since 1789 , trans. M.C. and M.F. Cleary (Cambridge, 199I), p. 127. The lack of concern with the Dreyfus Affair is well documented in Wilson's sociological analysis of anti-Dreyfusism: see his Ideology and Experience, pp. I26-I34.

83. "Propos de l’Instituteur", CP, pp. 237-243, esp. 240-24I, 3I July i904.

84. “Trop Tard!", p. I84.

85. On state corruption, see his short story "Un point de vue", CCII, pp. 30I-305, I6 December 1894, and the section entitled "En Mission" of Le Jardin des supplices (Paris, 1991), pp. 65-140. 86. On this point, see Wilson, Ideology and Experience, pp. 69-74.

87. Blum, Souvenirs, p. 77. On this political move, see Venita Datta, “'Passing Fancy?' - The Generation of I890 and Anarchism”, Modern and Contemporary France, 44 (I99I), pp. 3-IO.

88. Blum, Souvenirs, p. I47. 
had been drilled into him at the Jesuit college. ${ }^{89}$ As Michel has noted, Mirbeau's first struggle was against himself.' ${ }^{\circ}$

Mirbeau's activities in the Dreyfusards' campaign, and his subsequent understanding of its lessons, remove any doubts about his commitment to anarchism. Prior to the Affair his preferences had been clear: one could point to his friendship with Pissarro and Jean Grave, the preface that he wrote for Grave's La Société mourante et l'Anarchie, his abstentionist polemic "La grève des electeurs", and his thoughtful commentaries on the terrorist actions carried out by Ravachol and Emile Henry. ${ }^{91}$ However, after the Affair, his political preferences became still clearer. While so many of the loosely anarchist Dreyfusards followed Blum into the SFIO, Mirbeau went on to question the status and nature of political activity within France.

\section{A CONSERVATIVE SOCIETY}

Many Dreyfusards grew disillusioned with all forms of Republican politics. As a result of his experiences in the Affair, Charles Péguy was led to devise his famous formula that each protest movement starts as an honourable "mystique" and ends as a debased "politique". He was dismayed by the reduction of the Dreyfusard idealism to the anti-clerical demagogy of Combes. ${ }^{92}$ Georges Sorel was also initially an enthusiastic follower of Dreyfusard Republicanism. After the Affair, he considered that

The Dreyfusards have succeeded in passing many social reforms, with the aim of drawing the poor classes, who fill them with terror, to support the government. A new philosophy has been created to persuade the rich that they have a great social duty to fulfil: that of paying high taxes to allow the State, created by the Affair, to spread benefits to the poor. They call this the philosophy of solidarity, but it would be more accurate to name it the philosophy of hypocritical cowardice. ${ }^{93}$

As is well known, Sorel then transferred his sympathies from Republicanism to the Confédération général du Travail's (CGT) revolutionary syndicalism, before growing pessimistic about any possibility of meaningful political action to reform society. ${ }^{94}$

Compared with Blum, Péguy and Sorel, Mirbeau proved more consistent. He certainly experimented with further cooperation with Jaurès, contributing articles to L'Humanité. However, he never joined the SFIO, and by

89. His two self-explanatory texts are "Souvenirs!" and "Palinodies!", pp. 203-209.

90. Combats, p. II

91. All these texts can be found in CP.

92. Charles Péguy, Notre Jeunesse (Paris, 1969; ist pub. I910), p. Io6.

93. Georges Sorel, La Révolution dreyfusienne (Paris, 1988; Ist pub. 1906), pp. 20-2I.

94. One can find a number of accounts of Sorel's complex political trajectory. In my opinion, the most convincing is in Jeremy Jennings, Syndicalism in France: A Study of Ideas (New York, I990), pp. I04-IO9. Jennings cautions against accepting any easy association between Sorel and the proto-fascists of Action française, and explicitly criticizes Sternhell's interpretation of Sorel. 
1904 had withdrawn from the Humanite team.95 For the post-Dreyfusard Mirbeau, Jaurès's socialism did not provide the political solution to France's problems. Rather than following Blum in accepting this "new" socialism, Mirbeau shared something of Sorel's disillusion..$^{96}$

Another, quite different, theme emerged in Mirbeau's writing. For Péguy, Sorel and Blum, the long-term effects of the Dreyfus Affair were to push them into new attitudes to political action: ultimately negative attitudes in the cases of Péguy and Sorel, on balance more positive for Blum. However, when Mirbeau eventually left the post-Dreyfusard Republican-Socialist alliance his writings were suggesting a different type of analysis of the power of the right, and of the nature of political power itself.

$\mathrm{Up}$ to this point, we have stressed the political status and activities of right-wing movements. But what if the overt political action of these movements were merely an aspect of their global presence within French society? What if the socio-psychological analysis of such movements is more accurate (or perceptive) than the analyses provided by either Rémond or Sternhell??7 Mirbeau's analyses of right-wing political culture are clearly closer to the ideas of the social-psychological left than they are to those of Rémond or Sternhell.

He turned once again to examine the people of rural France. Once, he had idealized such communities. Then, during the Dreyfus Affair, he had despaired of them. However, there was also a third theme within his writing on this theme, which emerged as early as I884. While on a walking holiday in the Yonne, he had noted that each village and small town had its "rue de la Republique", its "square Gambetta" and its "place de la Nation". ${ }^{98}$ Of course, such sights were not necessarily typical of rural France: in Brittany and other Catholic areas, Sainte Anne still towered over the railway stations, remaining a more powerful public symbol than the Republican figure of Marianne. ${ }^{99}$ But to assert that the countryside was simply conservative or reactionary was clearly incorrect: in some places, Republicanism had penetrated the countryside. Could this new political force liberate the rural people?

While never entirely negative, Mirbeau's conclusions grew more pessimistic. Republicanization had failed to produce a true unity within French society:

95. On his participation with l'Humanité, see Michel and Nivet, L'imprécateur, pp. 744-750.

96. On this point see P. Michel, "Préface to 'Paysage Politique', COM, 2 (1995), pp. 2II-220, esp. 2II, I5 December I909.

97. See Erich Fromm, The Fear of Freedom (London, 1976); W. Reich, The Mass Psychology of Fascism, trans. V.R. Carfagno (Harmondsworth, 1978; ist pub. 1942); Klaus Theweleit, Male Fantasies (Cambridge, 1987); see also the useful corrective to such ideas in Gilbert Allardyce, "What Fascism is Not: Thoughts on the Deflation of a Concept", American Historical Review, 84 (1979), pp. 367-398.

98. Octave Mirbeau, Sac au Dos (n.p., I99I; Ist pub. I884), p. 3I.

99. "Croquis des fêtes bretonnes", CB, pp. 7I-8I, esp. 73, I August 1887. 
At these tragic moments in which an entire people's destiny is to be decided, when I imagine that everyone who feels, who thinks and who loves must be moved by a common passion to defend [Dreyfus], nothing could be more painful to me than this empty and ugly indifference into which the countryside is sinking deeper and deeper. $^{\text {IO }}$

Rather than thinking about the fate of the nation, the rural people are still more likely to be motivated by their primitive hatred of strangers, and therefore to reject men such as Dreyfus.

This is the fraternity which has been created by the nationalists: Frenchmen are set one against the other, foreigners in their own country and, in any village, anything which is not of the village - whether animals or people - is "foreign" [...] this local nationalism makes the peasants more savage than the savages of central Africa. ${ }^{\text {IOI }}$

Under these conditions, the rural people were open to political manipulation. Mirbeau noted the relative success of candidates from the populist right in gaining rural votes, and wrote several eloquent, bitter satires of their electoral practices.

"What does the peasant want?" a deputy said to me one day when he wanted to speak honestly. [He continued:]

"He wants promises, that's all. He wants enormous, incredible [promises] and, at the same time, he wants them to be clear [...] He doesn't ask that you make them come true; his wellknown voracity doesn't go that far; all he wants is that he can understand them. He's happy if they're about his cow, his fields, his house. And if he can talk about them, during the evenings, at get-togethers, on Sundays, at the church door or in the cabaret, if he can talk about them as things which could happen but which won't ever actually come about, then he'll think himself lucky. You can crush him with taxes, double his bills [. . .] He'll smile with a clever look, and with each new tax, with each new bit of administrative nonsense, he'll say to himself 'Okay, okay [...] go on if you like [...] I've got a deputy who'll stop these hassles one day. He's promised it!' "102

However, the rural Republicans seemed little better. In place of a grassroots, popular Republican movement, there arose a new, corrupt synthesis of the worst aspects of peasant culture with the most opportunistic aspects of Republican politics.

You knew straight away that the mayor was a good radical [Republican] [. . .] He wanted to serve the Republic, but [in the form] of what he called the "Peasants' Republic"; a wonderful Republic in which the peasants - and by this term he included all those who possessed a small or a large amount of land: bourgeois,

Ioo. "En Province”, p. 222.

IOI. Ibid., p. 223, and Dingo, p. 2 II.

I02. Octave Mirbeau, Les vingt et un jours d'un neurasthenique, ed. Hubert Juin (Paris, I977; Ist pub. I90I), p. 2I4. 
nobles and even the peasants - would not have to pay any taxes, nor be charged for anything. ${ }^{\mathrm{IO} 3}$

Under these circumstances, the Republicanization of the town hall led to few real reforms of rural society. Republican administrations even failed to lead their communes in a fight against typhoid - a disease which was curable by the i88os. During epidemics, projects for sanitary reform were dreamed up, and engineers would tour the countryside but, after the epidemic ebbed, such discussions died away. While the disease remained concentrated in the barracks and the hospitals, the middle-class officials who controlled the municipal administration could afford to ignore it. ${ }^{\mathrm{IO4}}$

Mirbeau also analysed the condition of rural popular culture under the Third Republic. He noted the penetration of alcoholic spirits into the smallest village cabaret, where the evenings started off with rounds of drinks and ended with bloody fights. ${ }^{\text {1os }}$ In many villages political rule was exercised by the cabaret owner, not the mayor. ${ }^{\text {106 }}$ Instead of awakening the rural people, Republicanism seemed to reinforce the old, corrupt forms of politics. Even public rituals remained unchanged from the Second Empire: the same military parades glamorized the bloody business of war. ${ }^{107}$

The rural people were culturally and intellectually impoverished, and they were also morally weak. Such people were unable to resist the intoxicating pull of Paris: a power of attraction which was made stronger by the increasing frequency of spectacular exhibitions. In Mirbeau's polemic against such exhibitions we can hear echoes of his previous hatred for Parisian mass culture.

This is no longer just a case of isolated individuals who, here and there, leave their field or abandon their workshop: this is a mob [foule], these are mobs, attracted by the prospect of high wages, by the promise of an easy, flashy life, by all that deceptive dream of Paris, which obsesses and turns the brains of these unhappy people; these are mobs, human tribes, who leave [the countryside] and who never return. ${ }^{108}$

It was this form of society which was perpetuating the rule of the Jesuits and the associated spirit of submission. Once again, at first sight Mirbeau's polemics can sound very similar to the classic themes of Republican anticlericalism. For example, he produces the following "Catholic" explanation for the nature of faith: "Faith consists in believing what your curé tells you,

I03. Octave Mirbeau, Dingo: roman, ed. C. Fritz (Paris, I978; Ist pub. 1913), p. 50.

I04. "Au pays de la fièvre", CB, pp. 83-94, I2 June I888.

I05. "Les Eaux muettes", CB, pp. 3I-6I, esp. 5I, I885.

106. Dingo, p. 58.

107. Sébastien Roch, pp. 1005-1007.

I08. "Pourquoi des Expositions?", in Octave Mirbeau, Combats Esthétiques, vol. II, ed. Pierre Michel and Jean-François Nivet (Paris, 1993) (hereafter CEII), pp. I07-I29, esp. I2I, I5 December I895. 
and in not believing a word of what your teacher tells you. ${ }^{\text {"og }}$ However, there was an unusual quality to Mirbeau's anti-clericalism. It was not so much equivalent to a statement of faith in Republican values as implicitly a critique of the Republicanism of the Third Republic, which - in Mirbeau's eyes - had so conspicuously failed in overturning the rule of the priest in rural society. "Clerical instruction is continuing hypocritically within secular instruction." "II The exploitation of the peasant by the priest formed the model for other, more modern forms of exploitation. "The peasant believes in God, because God speaks in Latin; he believes in the solicitor, as the solicitor writes in jargon."

These new forms of political culture neither created nor sustained any structures of social solidarity. The peasants wasted away their lives in "silly quarrels and stupid hates". ${ }^{112}$ In place of class solidarity, in place of vast collective movements of oppressed peoples, the rule of the bourgeoisie acted to annihilate collective identities. The bourgeoisie reigned alone, between two corpses: "the aristocracy and the people". ${ }^{113}$

Mirbeau does not glamorize the peasants, but neither does he condemn them for their ugly behaviour.

We must be indulgent to these poor beasts. Think! It was not so long ago, not even one hundred and twenty years ago, that they were oppressed, exploited, reduced to a condition far worse than that of animals by the seigneurs, bishops, monks, abbeys and royal tax-inspectors [...] Without them realizing it, they retain a sense of terror from those dreadful centuries [...] Even after their [civil] emancipation, they still have the mistrust, the panic of a hunted animal. Evolution occurs so slowly that it is no surprise that they still see in anyone who is better dressed, better taught and more polite, their old enemy. ${ }^{\mathrm{II}}$

Within Mirbeau's writing, these images of rural society serve as models by which to understand the political and moral condition of the majority of the nation. Mirbeau's Journal d'une femme de chambre, written during the struggles of the Dreyfus Affair, described a similar sort of sub-political world, where chambermaids, cooks, valets and chauffeurs react in a confused and naive manner to the great ethical questions thrown up by the Affair. Without demeaning these lower-class characters, Mirbeau demonstrates their inability to think through the issues involved: implicitly, once again, he is criticizing the failure of the Republican tradition to provide a meaningful mass education. It is no surprise to learn that the only medium easily available to them by which they can express their frustrations with their social situation is through the anger and violence of the anti-Dreyfusards.

I09. Octave Mirbeau, Le journal d'une femme de chambre (Paris, n.d.), p. 253.

IIO. Octave Mirbeau, La 628-E8 (Paris, 1977; Ist pub. 1905), p. 39.

III. Dingo, p. IO2.

II2. Ibid., p. 2II.

II3. "Regard derrière une planche", CEII, pp. I9I-I95. esp. 194, 9 May I897.

II4. Dingo, p. 2 I4. 
Given his despair with the condition of French political life, it is no surprise that Mirbeau insists on the accuracy of the anarchist critique of parliamentarism. "Any social problem, any economic solution, all public interests are captured [by parliament] and subordinated to the dominant question: the electoral question." ${ }^{\text {II }}$ No parliamentary movement, no matter how earnest its ideals, no matter how honest and dedicated its leaders, was capable of cutting through these structures of corruption, fear and ignorance within which the mass of the population lived.

It was these factors which led to the Dreyfusards' hollow victory. Dreyfus was released from prison, but the minds of the mass of the people remained imprisoned. Under such circumstances, given the conservative nature of popular culture, given the incomplete nature of the "emancipation" produced by Republican rule, fascism, proto-fascism or right-wing populism call it what you will - was the inevitable consequence.

\section{CONCLUSION}

Obviously, Mirbeau did not possess the gift of prophecy: he did not predict the political struggles of the I930s and I940s, and had no knowledge of the forthcoming growth of fascism. However, as we look back through the troubles of the mid-twentieth century to Mirbeau's writing, we can recognize a number of features. Within late nineteenth-century France, Mirbeau noted the development of a new type of right-wing political culture which, if we accept Mirbeau's observations, seems to resemble fascism.

However, in contrast to the research undertaken by Zeev Sternhell, Mirbeau does not analyse these new forms of right-wing activism as sets of ideas. ${ }^{116}$ The movement which Mirbeau opposes is all too physical in its presence in the streets and meeting-places. The origins of fascism are not to be found in occasional debates between disillusioned syndicalists and opportunist royalists, but in the physical violence perpetrated by antiDreyfusard militants, in their threats of violence and in the violence of the manner in which they communicated.

Through Mirbeau's writing one gains a vivid impression of the wide variety of right-wing political cultures. In the i870s, the right had seemed to be a nexus which could join rural communities, elegant ladies and even innovative artists into an alliance against a threatening, degrading mass culture. However, in the I88os, other themes became prominent within the right. Instead of fighting the Paris-based state, new right-wing movements sought to capture it; instead of proposing decentralization, they became

II5. "Paysage Politique", p. 215.

II6. For a useful critique of Sternhell's "idealistic" historiography, see Jacques Julliard, "Sur un fascisme imaginaire: à propos d'un livre de Zeev Sternhell”, Annales ESC, 39, 4 (1984), pp. 849859 . 
centralists. These ideas were crystallized in the nationalist strategy of the authoritarian alliance of the church and army, a formation which was proposed by the anti-Dreyfusards' campaign, and in their normalization of forms of violence - physical, symbolic, cultural - as political tactics.

Mirbeau's understanding of the nature of the right-wing politics also changed. In the I870s, he saw it as an "organic" force, almost as a natural growth within French society. In the I880s and I890s he stressed its basis in the institutions of the church and army. Finally, he moved to perhaps a more subtle position, suggesting that right-wing populism was the inevitable reaction to the Republicans' half-hearted republicanization of French society.

Above all, throughout Mirbeau's writing there are detailed descriptions of both the simple power of right-wing movements, and of their success in adapting to the new conditions of the epoch of mass politics.

Of course, Mirbeau may well be wrong. His writings are fierce, partisan polemics: hardly the sort of material which historians usually make the basis of their interpretations. The inaccuracies in his simplistic depictions of French politics are so obvious that they are hardly worth listing: one could start by noting Mirbeau's failure to consider the small but significant growth of a left-wing peasantry, his blindness to the potential importance of the Christian-Democratic current within French Catholicism, and his refusal to note the ability of some Republicans to build a meaningful, and relatively honest, alliance with rural people. However, one could claim that these were minor faults: the lasting impression that one has from Mirbeau's writing on right-wing political culture is that of its ingrained strength within and against the structures of the Third Republic. If Mirbeau was right, this could go a long way to explain the relative failure of the left to achieve political power within France. 